\title{
The Diversion For Children In Front Of The Law In Traffic Accident Cases
}

\author{
Bagus Jatmiko*) and Bambang Tri Bawono**) \\ *) Police Resort of Semarang City (Polrestabes) E-mail: \\ goodj_mh36@std.unissula.ac.id \\ **) Faculty of Law Universitas Islam Sultan Agung
}

\begin{abstract}
The purpose of this study is to identify and analyze the implementation of diversion in the settlement of traffic accident cases committed by children in the context of legal certainty; knowing and analyzing the obstacles and solutions to the application of diversion in the settlement of traffic accident cases committed by children in the context of law enforcement that leads to restorative justice. This research approach method uses a sociological juridical approach. The conclusion of this study is that law enforcement officers in carrying out their duties of investigating, prosecuting, examining and determining case decisions for children who are in conflict with the law in traffic accident cases should prioritize the application of diversion as an alternative to the application of imprisonment. Massive socialization of diversion is needed to the community. The government should provide diversion facilities and infrastructure in order to guarantee protection for children.
\end{abstract}

Keywords: Diversion; Children; Law; Traffic Accidents.

\section{Introduction}

Child protection is an area of national development, ignoring the issue of child protection means ignoring national development. Because children are human resources for the development of a country where development starts as early as possible so that children can contribute optimally to the development of the nation and state.

Criminal law generally regulates people's lives so that public order can be created and maintained. ${ }^{1}$ Act No. 11 of 2012 concerning the juvenile criminal justice system, all of which state general principles of child protection, namely nondiscrimination in the best interests of children, respecting survival and growth and development. The presence of these regulations has formulated the protection of children's rights, but in reality they have not yet received treatment that is very beneficial for the best interests of the child.2

The rapid development of transportation will indirectly increase the risk of the growth of traffic problems, one of which is traffic accidents. According to Act No. 22

\footnotetext{
${ }^{1}$ Aan Hardiansyah, Tindak Pidana Kekerasan dalam Proses Belajar Mengajarditinjau dari perspektif hukum pidana dan Undang-undangNomor 14 tahun 2005 tentang gurun dan dosen, Jurnal Daulat Hukum Vol.1 No.1, March 2018 accessed from http://jurnal.unissula.ac. en/index.php/RH/article/view/2622/1972 on July 7, 2021.

2 Yul Ernis, Diversi dan keadilan restoratif dalam penyelesaian perkara tindak pidana anak di Indoensia, Jurnal Ilmiah Kebijakan Hukum,Vol.10,No.2 July 2016, p. 164.
} 
of 2009 concerning road traffic and transportation in Article 1 Point 24, the definition of a traffic accident is an event on the highway that is unexpected and unintentional involving a vehicle with or without other road users resulting in human casualties and/or losses property.

Traffic accidents generally occur due to various causative factors such as negligence of road users, vehicle unfitness, and road and or environmental unfitness in addition to that. The community's indiscipline in traffic has resulted in many traffic violations which are quite high and the ownership of private vehicles is increasing day by day, this will indirectly trigger traffic accidents. According to Article 229 Act No. 22 of 2009 concerning Road Traffic and Transportation in the form of traffic accidents is divided into 3 categories as follows:

- Minor traffic accidents are accidents that result in damage to vehicles and/or goods.

- Moderate Traffic Accidents are accidents that result in minor injuries and damage to vehicles and/or goods.

- A serious traffic accident is an accident that results in the victim's death or serious injury.

Every child must be given protection, one of which is to avoid the stigma of being a criminal to the child in society, it will have an influence on the child's growth and development. Criminal law has developed, until there is a paradigm shift in the philosophy of juvenile criminal justice, starting with retributive justice where criminals are fined according to their crimes, become rehabilitation, and finally become restorative justice.

Cases of children who are in conflict with the law $(\mathrm{ABH})$ which reach the judicial process are only serious cases (very disturbing), while still prioritizing the principle of the best interests of the child, not ignoring the rights of the child, and punishment is the last resort (Ultimate Remedium). So that cases of children dealing with $\mathrm{ABH}$ law can be resolved in a non-formal mechanism with standard guidelines. The form of non-formal handling in question is in the form of diversion, as is the process of mediation facilitated by law enforcement in order to achieve restorative justice, which is resolved by requiring children in conflict with the law (ABH) to attend education or training or other actions with the aim of restoring the child, if forced to happen punishment, the rights of the child cannot be ignored.

The purpose of this study is to identify and analyze the implementation of diversion in the settlement of traffic accident cases committed by children in the context of legal certainty; knowing and analyzing the obstacles and solutions to the application of diversion in the settlement of traffic accident cases committed by children in the context of law enforcement that leads to restorative justice.

\section{Research Method}

This research approach method uses a sociological juridical approach. Sociological juridical is a research carried out on the real situation of society or the community environment with the intent and purpose of finding facts (fact-finding), which then leads to identification (problem identification) and ultimately leads to 
problem solving (problem solution). ${ }^{3}$ The specification used in this research is descriptive analytical which reveals the laws and regulations relating to legal theories that are the object of research. ${ }^{4}$ While the method used to perform data analysis is descriptive qualitative.

\section{Results and Discussion}

\subsection{Implementation of diversion in solving traffic accident cases.}

The definition of children according to Act No. 35 of 2014 concerning Child Protection Article 1 point 1 explains that a child is someone who is not yet 18 years old, including a child still in the womb. Children have specific rights that are different from the rights of adults, this is due to the fact that children are very vulnerable to violence and exploitation. ${ }^{5}$ The forms of crime and criminal acts that are mostly committed by children include fighting, theft, drug trafficking, crimes of sexual harassment, molestation, traffic violations, traffic accidents where the perpetrators are children. Various criminal cases involving children having to deal with the law are actual and factual problems as social and criminal phenomena that have raised concerns among parents in particular and society in general as well as law enforcers. ${ }^{6}$ Efforts to protect children can be a legal action that has legal consequences, thus preventing children from arbitrary parental actions. ${ }^{7}$

Act No. 11 of 2012 concerning the juvenile criminal justice system, all of which state general principles of child protection, namely non-discrimination in the best interests of children, respecting survival and growth and development. The presence of these regulations has formulated the protection of children's rights, but in reality they have not yet received treatment that is very beneficial for the best interests of the child. ${ }^{8}$ The most basic substance in this law is a strict regulation of restorative justice through the diversion process which is intended to avoid and keep children away from the judicial process so as to avoid stigmatization of children who are in conflict with the law and it is hoped that children can return to the social environment naturally. . ${ }^{9}$

\footnotetext{
${ }^{3}$ Soejono Soekanto, 1982, Pengantar Penelitian Hukum, UI Press, Jakarta, p. 10.

4Soerjono Soekanto,2001, Penelitian Hukum Normatif: Suatu Tinjauan Singkat, Jakarta: Rajawali Press, p. 105-106.

5 Nur Rochaeti, Implementasi Keadilan Restoratif dan Pluralisme Hukum dalam sistem peradilan pidana anak di Indonesia, Jurnal Masalah-Masalah Hukum, Vol.44 No.2, April 2015, p.150.

6Ulang Mangun Sosiawan, Perspektif Restorative Justice Sebagai Wujud Perlindungan Anak yang berhadapan dengan hukum, Jurnal Penelitian Hukum DE JURE, VOl.16 No.4 December 2016, p. 428.

${ }^{7}$ Moch. Faisal Salam, 2005, Hukum Acara Peradilan Anak di Indonesia, Ed. I, Mandar Maju, Bandung, p 1.

8 Yul Ernis, Diversi dan keadilan restoratif dalam penyelesaian perkara tindak pidana anak di Indoensia, Jurnal Ilmiah Kebijakan Hukum,Vol.10,No.2, July 2016, p. 164.

9 I Dewa Putu Gede Anom Danujaya, Formulasi Model Sistem Pemidanaan Anak di Indonesia, Jurnal Daulat Hukum $\quad$ Vol.1 $\quad$ No.1 $\quad$ March 2018 accessed from http://jurnal.unissula.ac.id/index.php/RH/article/view /2624/5117 on 7 July 2021.
} 
The definition of diversion is the transfer of the settlement of children's cases from the criminal justice process to processes outside of criminal justice. The implementation of diversion has the following objectives: ${ }^{10}$

- Achieving peace between victims and children;

- Resolving child cases outside the judicial process;

- Protecting children from deprivation of liberty;

- Encourage community participation and;

- Instill a sense of responsibility in children.

The application of diversion in the case of children in conflict with the law must be carried out at every level of examination starting from the level of investigation, prosecution and case examination. The diversion requirement can be carried out, namely that the crime committed is punishable by imprisonment for under 7 (seven) years, is not a repetition of the crime, and is carried out by children aged 12 years and over.

The purpose of diversion is to find a way to deal with violations of the law outside the courts or the formal criminal justice system. There are similarities between discretionary goals and diversion. The implementation of diversion is motivated by the desire to avoid the negative effects on the soul and development of children by being involved with the criminal justice system. The implementation of diversion by law enforcement officers is based on the authority of law enforcement officers which is called discretion. ${ }^{11}$ The process in implementing diversion is carried out by deliberation between the parties involving the child and his/her parents/guardians, victims and/or their parents/guardians, community advisors and professional social workers and may involve social welfare workers and/or the community.

Throughout 2020 in the city of Semarang there have been 939 traffic accidents with 152 deaths, zero serious injuries, 928 minor injuries and material losses of IDR $387,950,000$. For traffic accidents involving children as many as 272 people. ${ }^{12}$ However, not all traffic accidents make children the perpetrators, some become victims as well. In 2018 until May 2021, the Polrestabes Semarang carried out diversion for children who are in conflict with the law in traffic accident cases as many as 4 (four) cases which have been completed in the filing. This shows that the implementation of diversion for children who are in conflict with the law in traffic accidents has been going on. In the implementation of diversion for children who are in conflict with the law in traffic accident cases, there are advantages, namely:

- Children do not need to be detained and prevent children from participating in the judicial process by keeping children away from the negative influences and implications of the judicial process;

- Avoid being stigmatized as a criminal;

10 Setya Wahyudi, 2011, Implementasi Ide Diversi dalam pembaharuan sistem peradilan anak di Indonesia, Yogyakarta, Genta Publishing, p 67.

${ }^{11}$ Marlina, 201, Pengantar Konsep Diversi dan restorative Justice dalam hukum pidana, Medan : USU Press, p.2.

${ }^{12}$ Data on the incidence of traffic accidents at Polrestabes Semarang in 2020. 
- Opportunities for children to improve their education and life skills;

- Opportunities for children to be responsible for their actions;

- So that the child does not repeat his actions again.

- Provide justice for victims of traffic accidents with diversion.

\subsection{Obstacles and solutions to the application of diversion in solving traffic accident cases committed by children}

The emergence of the idea of diversion in restorative justice efforts as a criticism of the implementation of the criminal justice system with imprisonment is not effective in resolving social conflicts. The reason is that the parties involved in the conflict are not involved in conflict resolution. Victims are still victims, perpetrators who are imprisoned also create new problems for their families and so on. ${ }^{13}$ In implementation in the field there are also several obstacles that must be faced, among others:

- Many people do not understand about diversion. People still think that if there is a traffic accident case committed by someone, it must be processed through legal channels (the court). Likewise with traffic accidents cases that make children as perpetrators who cause traffic accidents to occur. In addition, the victim's family and the child's family as part of the community also do not understand about this diversion.

- Not reaching an agreement on diversion, when determining an agreement between the victim and the child is not easy. At the time of the diversion deliberation, when the children in conflict with the law and the victims of traffic accidents meet in the diversion room, quarrels or commotions often occur which result in the diversion deliberation being not conducive. Even the demands of the victim's family are excessive so that the family of the perpetrator (the child) cannot fulfill it so that no agreement occurs. Sometimes the victim's family does not want to agree with the diversion method for reasons of justice. For this reason, it can be interpreted that the difference in interests between the two is a fundamental problem in determining the agreement.

- Different understanding in handling children in conflict with the law. Law enforcers sometimes have different understandings regarding the implementation of handling children who are in conflict with the law in traffic accident cases. In addition, the lack of cooperation and communication between law enforcement and child social workers and Bappas is also a separate obstacle in the implementation of diversion.

The application of diversion to children who are in conflict with the law in traffic accident cases is the implementation of a system in restorative justice to provide justice and legal protection to children. For this reason, the solutions to overcome these obstacles include providing understanding to victims and their families that diversion is not a peaceful effort but a form of punishment for children

13 Aryani Witasari, Implementasi diversi guna mewujudkan restoratif justice dalam sistem peradilan pidana anak, Jurnal Hukum Vol.35 accessed from http://jurnal.unissula.ac.id/index.php/jurnal Hukum/article/view/11052/4249 on June 25, 2021. 
who are in conflict with the law in a non-formal way. Diversion is a form of punishment that has an educational aspect to children, not retaliation, considering that children are important in preparing Indonesia's future.

Establish communication and cooperation between law enforcement authorities in this case investigators with child social workers and Bappas. This is one of the important factors in the implementation of diversion for children who are in conflict with the law in traffic accident cases.

\section{Closing}

Accident cases caused by children and adolescents are a separate problem in law enforcement. Therefore, the application of diversion can provide justice and legal protection to children who are in conflict with the law in traffic accident cases. There are obstacles in the implementation of diversion for children who are in conflict with the law in traffic accident cases, which include many people who do not understand about diversion, not reaching an agreement on diversion and different understandings in handling children in conflict with the law. The solution to these obstacles is to provide understanding to the victim and the victim's family that diversion is not a peaceful effort but a form of punishment for children who are in conflict with the law in an informal way.

The suggestions that can be submitted in this study are for the Government to provide facilities and infrastructure in the implementation of diversion in the context of guaranteeing protection for children, for law enforcement when facing children who are in conflict with the law in traffic accident cases to prioritize the implementation of diversion as an alternative to implementation of imprisonment, while victims and parents should be able to understand the implementation of diversion for children who are in conflict with the law in traffic accident cases.

\section{References}

\section{Journal}

[1] Aryani Witasari, Implementasi diversi guna mewujudkan restoratif justice dalam sistem peradilan pidana anak, Jurnal Hukum Vol.35 accessed from http://jurnal.unissula.ac.id/index.php/jurnalhukum/article/view/11052/42 $\underline{49}$ on 25 June 2021.

[2] Aan Hardiansyah, Tindak Pidana Kekerasan dalam Proses Belajar Mengajarditinjau dari perspektif hukum pidana dan Undang-undangNomor 14 tahun 2005 tentang gurun dan dosen, Jurnal Daulat Hukum Vol.1 No.1 March 2018 accessed

from http://jurnal.unissula.ac.id/index.php/RH/article/view/2622/1972 on 7 Juli 2021.

[3] I Dewa Putu Gede Anom Danujaya, Formulasi Model Sistem Pemidanaan Anak di Indonesia, Jurnal Daulat Hukum Vol.1 No.1 March 2018 accessed from http://jurnal.unissula.ac.id/index.php/RH/article/view/2624/5117on 7 July 2021. 
[4] Nur Rochaeti, Implementasi Keadilan Restoratif dan Pluralisme Hukum dalam sistem peradilan pidana anak di Indonesia, Jurnal Masalah-Masalah Hukum, Vol.44 No.2, April 2015.

[5] Ulang Mangun Sosiawan, Perspektif Restorative Justice Sebagai Wujud Perlindungan Anak yang berhadapan dengan hukum, Jurnal Penelitian Hukum DE JURE, VOl.16 No.4 December 2016.

[6] Yul Ernis, 2016, Diversi dan keadilan restoratif dalam penyelesaian perkara tindak pidana anak di Indoensia, Jurnal Ilmiah Kebijakan Hukum,Vol.10,No.2 July 2016

\section{Book}

[1] Marlina, 2016, Pengantar Konsep Diversi dan restorative Justice dalam hukum pidana, Medan : USU Press.

[2] Moch. Faisal Salam, 2005, Hukum Acara Peradilan Anak di Indonesia, cetakan I, Mandar Maju, Bandung.

[3] Setya Wahyudi, 2011, Implementasi Ide Diversi dalam pembaharuan sistem peradilan anak di Indonesia, Yogyakarta, Genta Publishing.

[4] Soejono Soekanto, 1982, Pengantar Penelitian Hukum, UI Press, Jakarta.

[5] ---------------, 2001, Penelitian Hukum Normatif: Suatu Tinjauan Singkat, Jakarta: Rajawali Press.

[6] Ronny Hanitijio Soemirto,1995, Metodologi Penelitian Hukum Dan Jurimetri, Jakarta, Ghalia Indonesia.

[7] Tatang M.Amirin, 1995, Menyusun Rencana Penelitian, Cet.3, Raja Grafindo Persada, Jakarta.

\section{Regulation}

[1] Constitution 1945 of Republic of Indonesia.

[2] The Criminal Code.

[3] The Criminal Procedure Code.

[4] Act No. 4 of 1979 concerning Child Welfare.

[5] Act No. 22 of 2002 concerning the National Police.

[6] Act No.23 of 2002 on Child Protection.

[7] Act No. 22 of 2009 concerning Road Traffic and Transportation.

[8] Act No.11 of 2012 concerning Juvenile Justice System.

\section{Other}

Data on the incidence of traffic accidents at Polrestabes Semarang in 2020. 